\title{
Shaming an Unwilling Host: The Chilean solidarity movement, Fall 1973
}

\author{
Francis Peddie, Nagoya University, Japan
}

Throughout its history, Canada has often become a place of refuge for people who suffered oppression in their countries of origin. In the 1970s, one such group consisted of Chileans who fled their homeland after the coup d'état that toppled the government of President Salvador Allende on 11 September 1973. With the overthrow of Chile's experiment in democratic socialism and the state repression that followed, hundreds of thousands of people from all walks of life left the country, resulting in la diáspora chilena, the Chilean diaspora. ${ }^{1}$ Often they left under duress or out of fear for their lives and those of their families. In many cases, the persecuted had no plan to escape to a particular country of refuge; they took shelter wherever they could. In this context, by October 1973 Canada became a place of refuge for Chileans forced from their homes. While Canada did not shelter as many as some other nations, it nonetheless has played a significant role in the Chilean diaspora. ${ }^{2}$

As this study will argue, the presence of Chilean exiles in Canada is the result of the concerted pressure on the federal government by leftist or left-leaning parties and organisations, in the face of denial in Ottawa of the severity of the humanitarian crisis in Chile. The coalition working in solidarity with persecuted Chileans included the New Democratic Party (NDP), the Parti Québécois (PQ), and smaller parties, such as the Communist Party of Canada; organised labour, through the Canadian Labour Congress and the Confédération des syndicats nationaux; non-governmental organisations such as Amnesty International and Oxfam; concerned academics, under the banner of the Canadian Association of University Teachers (CAUT) and the World University Service (WUS); citizens' groups, such as the Toronto Welcome Committee for Chilean Refugees and the Comité d'accueil pour les Réfugiés Chiliens in Quebec; and, perhaps most importantly for the Chilean question, progressive elements within various Christian denominations, many under the umbrella of the Canadian Council of Churches (CCC). ${ }^{3}$ This agglomeration of disparate but like-minded bodies lobbied the federal government to allow Chileans in under relaxed immigration criteria and assist in their passage, citing the precedent of special admissions programmes for Hungarians (1956-7), Czechoslovakians (1968), Tibetans (1971), and Ugandans of Asian descent (1972).

In the fall of 1973, the attitude and actions of representatives of the Canadian government came under heavy criticism for a perceived unwillingness to cooperate fully in resettling Chileans whose lives were in danger. During the 
Cold War, admitting people associated with the political left was problematic for reasons connected to internal security and reflected an ideological bias against supposed members of the enemy camp. Officials working for the ministries of Manpower and Immigration (the forerunner of today's Department of Citizenship and Immigration) and External Affairs initially reacted to the coup d'état and subsequent humanitarian crisis with a mixture of distaste for the victims and ignorance of their plight. I will discuss the obstacles to accepting Chileans and how these barriers were overcome through the solidarity activities of progressives within Canada. I will also show how the success of the Chilean refugee lobby at influencing changes in policy and practice had longer-term outcomes for human rights issues and solidarity movements throughout the 1970s and into the following decade.

My research on this topic draws largely on internal government documents, including diplomatic telegrams between Ottawa, Santiago and other consulates in Latin America in the fall of 1973 that illustrate anti-leftist bias and the reluctance of the federal government to act decisively to assist the persecuted in Chile. Criticism of government (in)action formed an integral part of the solidarity network's public campaign for the acceptance of refugees from Chile, and is a continuing motif in the newsletters, reports and press releases from the time. These primary sources constitute the backbone of this study, along with Hansard records from the House of Commons that show the debates over the Chilean issue at the highest level of government.

Recent scholarship on the Chilean experience in Canada, such as José Del Pozo's Les Chiliens au Québec: Immigrants et réfugiés, de 1955 à nos jours or Julie Shayne's They Used to Call Us Witches: Chilean Exiles, Culture, and Feminism largely focus on the points of view, lived experiences, and community activities of exiles and immigrants. Studies such as these provide invaluable insight into the memories and opinions of the people who resettled in Canada, and the challenges they faced. ${ }^{4}$ In my own doctoral research on this topic, I also devoted attention primarily to the testimony of twenty-one Chilean exiles about how and why they came to Canada, and what kind of lives they had in a new country that was in many ways for them a kind of "golden cage." Immigration historians in recent years have increasingly concentrated on the people involved rather than the processes and institutions, in part as a reaction to the tendency identified by Harold Troper in 1988 of Canadian historical writing to be "largely preoccupied with the interests of the gatekeepers, ignoring those who pass through the gates."

However, this particular examination features a strong "top-down"element insofar as it looks at government policy and the decisions and thought processes of elite actors, such as ambassadors and government ministers. This focus is essential when we consider the Cold War context in which the Chilean crisis played out. As Franca Iacovetta illustrated in Gatekeepers: Reshaping Immigrant Lives 
in Cold War Canada, Cold War anxieties had a deep impact on Canadian immigration policy, reception and citizenship programmes, and in government circles created a conservative consensus about the need to battle communist influence both at home and abroad. ${ }^{7}$ While the successes of the solidarity lobby described in this article highlight the limits of government power in the face of sustained public pressure, we cannot ignore the fundamental role of institutions and policies in the acceptance and rejection of Chileans seeking shelter in Canada.

The emergence of a solidarity lobby around the Chilean crisis resulted from changes in social and political beliefs and movements at both the international and domestic level. To begin, let us look first at the Unidad Popular administration that governed Chile from 1970 to 1973 and its international appeal to understand why a coup in a distant and largely unknown country provoked such a rapid and passionate response among progressive groups across Canada.

\section{The "Chilean Road to Socialism"}

Riding on Chile's narrow shoulders was nothing less than a world historical test of whether the transition to socialism could be achieved through democratic, peaceful methods. If it could be done in Chile, then it could be done in Italy or France or...8

Salvador Allende was elected president of Chile in September 1970 as the head of a coalition of a half-dozen left and centre-left parties known as the Unidad Popular (Popular Unity, henceforth UP). The UP, with the Communist Party and Socialist Party at its core, vowed to use state institutions and legislation to create a socialist system gradually. Allende himself promised "the first socialist society built according to the principles of democracy, plurality and liberty.", The transformation to socialism, the UP leadership claimed, would be in the best interest of the nation: it would make Chilean society more egalitarian and end dependence on foreign interests by using the country's natural wealth for the good of all citizens. ${ }^{10}$ This strategy, the "Chilean road to socialism," was unorthodox and unique, and captured the imagination not just of Chileans, but of people around the world.

In Canada, religious bodies such as the Ecumenical Forum and organisations interested in political and social issues, like the Latin American Working Group (LAWG) in Toronto, looked at what was happening in Chile as the birth of "an egalitarian, humanistic society without the violent methods used elsewhere."11 The interest in the UP project from groups in Canada reflected an increasing engagement in Latin America at state and popular levels. On one hand, throughout the 1960s the nation attempted to redefine its place in the world order and the international market as being distinct from the United States, which resulted in more focus on Latin America as a potential source of allies and trading partners and culminated in a new foreign policy focus on the 
region starting in 1968. ${ }^{12}$ At the non-state level, Canadians who sympathized with countries who were attempting to decolonize or assert their economic and political sovereignty looked to Latin American states such as Cuba as leaders of the Third World movement, but were also engaged by negative events such as the American invasion of the Dominican Republic in $1965 .{ }^{13}$

For New Leftists who sought a different option than American-style capitalism, with its acceptance of inequality, or Soviet-style communism, with its rigid system of control and lack of freedoms, the UP project represented a third way, combining participatory democracy with social justice. ${ }^{14}$ Furthermore, the peacefulness of its methods and its efforts to alleviate poverty and other social ills made the UP attractive to Christians of all denominations, especially given the influence of liberation theology on small but vocal groups within the churches who manifested a "sense of Christian activism that coincided with Canadians' growing acceptance of pluralism and more liberal social norms."15 Like other socialists and social democrats around the world, leftist groups and individuals in Canada watched the developments in Chile after 1970 with great interest and hope, but also with a sense of trepidation; given the geopolitical reality of the time, how far would the UP project be able to go? Could a moderate approach to instituting far-reaching political, economic and social change work in a time of ideological polarisation and superpower intervention?

It could not. Despite notable achievements in the first two years of its mandate, by October 1972 the UP government faced chronic internal crises and external manipulation that made the prospects for its survival increasingly unlikely. ${ }^{16}$ Congress faced legislative deadlock, and capital flight and a campaign of economic non-cooperation and obstruction led by the Chilean business elite created a sense of instability. Chile also experienced increasing polarisation on the social level, as the country split between supporters of the UP and the government's opponents, creating a divide that sowed animosity and eventually led to violent street clashes between militants from the right and left. ${ }^{17}$

External pressure led by the Nixon administration in the United States contributed to the state of unrest. The US government had opposed the UP from the first, and when covert attempts to keep Allende from power failed, the Americans and their Chilean allies settled on a different approach: to sabotage the country's economy by withholding credit, foreign investment and vital industrial materials, or in the words of Richard Nixon, to "squeeze [Chile] until it screamed." 18 Economic instability deepened and accentuated social division and disorder, creating conditions that would work against the establishment of "a second communist state in the Western Hemisphere," something the US government viscerally feared since the success of the Cuban Revolution barely a decade earlier. ${ }^{19}$ 
This combination of internal division and external interference created the desired effect. By 1973, Chile was destabilized and the UP government was on precarious ground. The anti-UP leaders hoped for an electoral solution to the situation, but this proved fruitless when the UP garnered $43 \%$ of the vote in Congressional elections in March 1973. Denied the two-thirds majority it needed to impeach the president and end the UP project by legal means, an increasing number of Chileans contemplated extra-constitutional methods to restore order through military intervention. ${ }^{20}$

The Chilean Armed Forces had not directly involved itself in political affairs since the 1930s and was seen both by Chileans and outsiders as professional and neutral. ${ }^{21}$ Respect for the institution was widespread, and Allende had brought high-ranking military men into his cabinet in November 1972 as one of the conditions for ending a truckers' strike. However, there is evidence that by that point, systematic plans to take over the government were already being developed by middle-ranking officers in all three branches of the military. ${ }^{22}$ The political deadlock confirmed by the March election brought more officers onside, and by September 1973 the military leadership was putting the final touches on the takeover plan. Known leftist strongholds were searched for weapons, the military garrisons throughout the country were put on alert on 1 September, and on 10 September around 50 pro-Allende officers in the army, navy and air force were arrested as a pre-emptive measure. ${ }^{23}$ The next morning, troops surrounded la Moneda, the presidential palace in downtown Santiago, and ordered Allende to surrender. He refused. Late in the morning the air force bombed the palace. At around 2:30 in the afternoon, after making a final radio address to the nation, Allende is believed to have committed suicide. The ministers of the government were hunted down and rounded up, as were UP politicians and party activists. Armed resistance to the coup was limited and ineffectual. By the end of 11 September, the nation was under complete military control. The Unidad Popular attempt at leading the country down the "Chilean road to socialism" was finished.

\section{Repression and reluctant refuge: the Canadian ambassador and the "riff- raff of the Latin American left"}

Even those who welcomed military intervention thought that it would be quick and relatively painless, and that the Armed Forces would return power to the civilian leadership as soon as order was restored. As it turned out, they were entirely wrong. Vowing to "extirpate the Marxist cancer" represented by the UP, the Armed Forces rounded up the movement's leaders and tens of thousands of supporters from all parts of society. ${ }^{24}$ Throughout the country, those connected to the UP were interned in makeshift concentration camps, with many tortured and hundreds summarily executed without due process. ${ }^{25}$ While the number 
killed in the initial crackdown is a matter of debate, it was at least two thousand, along with up to 80,000 people detained for at least 24 hours between

September 1973 and January $1974 .{ }^{26}$ The ferocity of the repression and breadth of its reach made many UP supporters fear for their lives and leaving the country their only viable option. Embassies in Santiago soon faced a crush of terrified people seeking asylum from a military regime that viewed them as "antipatriotic agents of foreign powers" - puppets of Cuba and the Soviet Union who had wanted to destroy Chile's liberal democratic institutions and make the country a totalitarian state. ${ }^{27}$

The embassies of Latin American countries, among which Mexico and Argentina played particularly prominent roles, became important havens from persecution, along with the legations of France, Switzerland, Sweden, Italy and Great Britain. Canada initially became involved in the Chileans crisis due to the presence of three adults and one child seeking asylum. ${ }^{28}$ Over the next two weeks, these four would be joined by thirteen others who were eventually given refuge at the ambassador's residence. Consular officials gave them shelter on the grounds that they were fleeing from insurgents attacking a government recognized by Canada. However, the acceptance of these fugitives set a precedent of assistance that some government officials found troubling.

One major influence on Canadian consular officials was the attitude of the ambassador himself. As was later leaked to the public, Ambassador Andrew Ross, who was in Buenos Aires at the time of the coup, quickly advised the government to recognize the junta:

$\mathrm{O}] \mathrm{n}$ [the] present reading and at this distance I can see no useful purpose in withholding recognition unduly. Indeed such action might even tend to delay Chile's eventual return to [the] democratic process. From my knowledge of [the] views of senior military officers unlike Brazilian or Peruvian models they would intend to turn [the] government back to [the] civil authority with [the] minimum delay feasible. ${ }^{29}$

Andrew Ross was later cast as a villain by people in Canada closely involved in the Chilean issue, and statements he made certainly did not paint him as sympathetic to the plight of those in danger or fully aware of the seriousness of the situation. His characterization of the Allende administration as "surely one of the most incompetent of recent times" echoed the accusations of the anti-UP Chilean media, as did his assessment regarding the military "[that] only with [the] greatest reluctance did they decide that [the] institutional disintegration and political madness of recent months had to be arrested by shock treatment." 30 As the junta consolidated control and began a defamation campaign against the overthrown government, Ross seems to have uncritically accepted reports of leftist guerrilla armies and the rampant misuse of state funds by UP politicians as true. However, his most infamous statement concerned foreigners 
in Chile in imminent danger due to the coup, and as we shall see later, it came back to haunt him:

With almost [the] entire leadership dead or in custody Chile's Marxist left is decapitated and on [the] run.[The] country's non political activity is returning to normal progressively and quite rapidly but curfew is still imposed [from] $3 \mathrm{pm}$ to $7 \mathrm{am}$. Reprisals and searches have created [a] panic atmosphere affecting particularly expatriates including [the] riffraff of [the] Latin American left to whom Allende gave asylum. These "activists" are running out of countries willing to accept them. ${ }^{31}$

If the embassies of the world represented the first sources of solidarity for the fugitives of the coup d'état, the attitude of the senior official on the ground gave little hope that Canada would play a constructive role in the Chilean crisis. However, while Ross was calling for recognition of the junta, in Canada progressive secular and religious groups began mobilizing to contest the ambassador's interpretation of events, and to pressure a reluctant federal government to assist the victims of the military regime.

\section{The solidarity movement takes action}

To claim that the solidarity with Chile coalition appeared solely as a reaction to the coup d'état would be misleading. Leftist organisations and other progressive entities had observed the Chilean situation with keen interest after the election of the UP, first with hope and then with dismay as the situation deteriorated. This study looks mainly at solidarity activities that took place in Ottawa and Toronto; however, the Chilean crisis provoked action and reaction from concerned individuals and entities across the country which worked under different names but shared the common goals of denouncing the coup d'état and assisting people in jeopardy because of it.

Even before the coup, the Latin American Working Group established a special Chile Project committee, anticipating a bad end to the crisis. ${ }^{32}$ On 12 September, this group met in Toronto with other sympathetic organisations, such as representatives of the Canadian Council of Churches (CCC), to form an Ad Hoc Committee on Chile, which would later operate under the name ChileCanada Solidarity. The Committee set as its immediate goals lobbying the federal government to withhold recognition of the junta and to admit refugees. ${ }^{33}$ Meanwhile, members of the Canadian Peace Congress, a group with ties to the Communist Party of Canada, held a demonstration at Toronto's City Hall to denounce the coup and appeal to the Canadian government to repudiate the actions of the Chilean Armed Forces. ${ }^{34}$ The following day in the House of Commons, NDP member John Rodriguez brought the Ad Hoc Committee's positions into the political arena by introducing a motion that the government of Canada refuse to recognize the junta and withdraw financial support for the 
Chilean government. ${ }^{35}$ Though the motion failed, it served to bring the Chilean question to the fore and show that the NDP would be the parliamentary standard bearer for this cause. In Quebec, meanwhile, union leaders voiced their concerns for the safety of Chilean workers targeted by military repression and called on the federal government to offer asylum, thus making clear that organised labour would also play the role of advocate. ${ }^{36}$

On 14 September, leaders of the Anglican, Roman Catholic and United Churches addressed a telegram to Mitchell Sharp, the Minister of External Affairs, which introduced one of the arguments why Canada should assist Chileans affected by the coup, that of the illegality of the junta's actions: One thing is clear, that a democratically-elected government has been violently overthrown...We caution against precipitous recognition of an unconstitutional regime. We request the Canadian government to do its utmost to so that constitutional government be restored as soon as possible... We urge the Canadian government to offer safe conduct and assistance to... refugees, and any Chileans who may wish to come to Canada. ${ }^{37}$

This communication was followed within days by a call from the Canadian Labour Congress which echoed the plea to withhold recognition of the military government and launch "a vast humanitarian effort to save the lives of thousands of political refugees." 38 On 17 September, the CCC continued the campaign to pressure the government to act. In a press release, the organisation began using an argument that would become a constant refrain in the Chilean solidarity campaign:

Since these refugees are in danger of their lives, under a very repressive military regime, we have only one option: to do what we can to save these lives. Canada opened her doors to refugees from Hungary, Czechoslovakia and Uganda. If we refuse to open our doors to people who are in danger under another type of political regime, this would mean that we had acted from political rather than humanitarian motives. ${ }^{39}$

The appeal to past practice with regard to Iron Curtain and Commonwealth refugees would serve as a weapon in the solidarity movement's arsenal when trying to convince the government and members of the public to do more to help displaced Chileans. In effect, it was a strategy to defuse Cold War-era fears of leftist infiltration by framing the Chilean situation as a humanitarian crisis that went beyond ideology.

Soon after, Chileans themselves became involved in the solidarity effort. On 20 September, a group of Chilean students studying in Canadian universities demonstrated in Ottawa to petition the federal government to grant asylum to political refugees, but were given a cool reception by unidentified officials who thought they were part of an extremist group. ${ }^{40}$ Distrust of reports from 
Chilean sources regarding military brutality was endemic among federal representatives, who accepted the claims emanating from Ambassador Ross in Santiago that the violence was being exaggerated by "radicals" and that the situation in Chile was returning to normal. ${ }^{41}$ It appears the embassy personnel even ignored first-hand testimony by Canadians on the ground in Santiago - mostly Québécois nuns and priests - of finding bodies on banks of Mapocho River, which runs through the Chilean capital. ${ }^{42}$ Federal employees on both ends of the continent seemed determined to view the 11 September takeover as little more than another Latin American palace coup, despite a mounting pile of evidence that it was something altogether more violent and far-reaching. ${ }^{43}$

Chilean exchange students were not the only actors from the academic world engaged in the asylum question. Local and national student and faculty groups formed to advocate for the Chileans. At York University in Toronto, approximately twenty students and teachers banded together to form the York Committee for the Defense of a Democratic and Independent Chile. The members also called for Canada not to recognize the junta, to provide asylum, and to raise and support censure motions in the United Nations. ${ }^{44}$ On the national level, the World University Service Canada started the Canadian University Committee for Refugee Chilean Professionals and Students, which worked with the Association of Universities and Colleges of Canada and the National Union of Students to secure spots in Canadian post-secondary institutions for sponsored professors and students. ${ }^{45} \mathrm{As}$ an ongoing project, the sponsorship placement effort had fairly modest results; however, as an act of solidarity it served a wider purpose, as "it sent a clear message to Chilean exiles and Canadian government officials that the Canadian intelligentsia was prepared and committed to this politically contentious cause." 46 The Chilean solidarity question was attracting participants across a broader front than traditional leftist parties and labour unions.

To the disappointment of the burgeoning Chile lobby, the federal government recognized the military regime on 29 September. The recognition issue soured the 3 October meeting between CCC representatives and Minister Sharp. The first of three delegations sent by the CCC to Ottawa between October and January 1974, the group encountered the same skepticism the Chilean student group had faced two weeks earlier. Mitchell Sharp used press clippings from Chile to claim that the situation was improving, claimed "these people don't want to come to Canada," and cast doubt on the credibility of the CCC sources. ${ }^{47}$ With recognition of the junta, one of the pillars of the solidarity movement's position had fallen, and the prospect of humanitarian action seemed dimmer now that the military regime in Chile had the Canadian government's tacit approval.

Despite this setback, the groups coalescing around the Chilean question 
remained undeterred, and began to see some results for their labours. On 7 October, sixteen of the seventeen asylum seekers from the Santiago embassy arrived in Montreal, having obtained special ministerial permits that would allow them to stay in Canada for a year while their refugee claims were processed. In addition, there is evidence that the External Affairs department was beginning to take the issue more seriously, and on 10 October a high-ranking immigration officer was tasked with going to Santiago to assess the situation and report back on the potential need for a special movement programme for Chile. ${ }^{48}$ The combination of domestic pressure and the growing evidence of the violence of the military regime was pushing Sharp and other government officials to take more concrete actions.

Recognition of the military government occurred during Parliament's summer recess, from 22 September to 14 October. When the House of Commons sat again on 15 October, Andrew Brewin immediately confronted Minister Sharp on the issue of recognition and the need to assist the persecuted inside Chile. In remarks criticizing Ambassador Ross' justification of the coup, the MP asked Sharp whether the government was willing to assist refugees by granting asylum, safe conduct and travel assistance, as had been done in the past. Sharp responded that the asylum seekers from the embassy had already safely landed in Canada, that officials from Ottawa and Buenos Aires were going to Santiago to assess the situation, and that if further action were taken, it would be in accordance with past actions: "I think the honourable gentleman can be sure we shall act with humanity in these matters as we always do." 49

While Brewin continued to raise questions about the government's response to the refugee crisis throughout October, at the end of the month Chile-Canada Solidarity issued a call for individual Canadians to step forward to sponsor Chileans as immigrants. The group promised help both in the process of matching Chileans to sponsors and with filling out the necessary paperwork for the formal declaration required by immigration authorities, and outlined the responsibilities of sponsorship. ${ }^{50}$ As a tactic, it mirrored the actions of the academic community and removed the need for Chileans to prove being in danger to doubting embassy staff and immigration officers in Santiago. The call also mentioned the establishment of a special immigration assistance fund being planned in conjunction with, and under the administration of, the CCC. This fund would materialize the following month as the Canadian Fund for Refugees from Chile. ${ }^{51}$

By the end of October 1973, the religious, labour, academic and other diverse organisations across Canada involved in the Chilean solidarity movement had developed a plan of action, arguments and tactics, and established a degree of cooperation between different entities through umbrella groups such as Chile-Canada Solidarity in Ontario. Although their call to withhold recognition 
of the junta had gone unheeded, there were small signs that they were making headway on the humanitarian issue of refuge for the persecuted. Progress on this front, however, was slow. Mitchell Sharp might claim in Parliament that Canada would act from humanitarian impulses, but in reality suspicion about UP adherents continued to inform the actions of government officials, as the scandal involving Ambassador Ross that surfaced in November 1973 would make clear.

\section{The Ross telegrams}

On 5 November, NDP MP John Harney put forward a motion in the House of Commons for the recall of Andrew Ross, on the grounds that the ambassador had betrayed "a bias that makes it impossible for him to carry out stated government policy on political refugees in Chile." 52 The motion did not pass, but it marked the beginning of an episode that caused the government embarrassment and provided the Chilean lobby with ammunition in its fight to open Canada's doors. The fallout from the publication of leaked telegrams between Ambassador Ross and the department of External Affairs made government representatives rethink Canada's approach to the crisis in Chile, and in the end contributed to the establishment of a special programme to help Chileans in peril.

Harney made his motion because of what he had read in a series of confidential communiqués which had passed between Santiago and Ottawa in September, starting just before the coup and continuing until 29 September, the day Canada announced it would recognize the junta. Harney in turn passed on a number of them to the LAWG, which promptly published them in a November issue of the Chile-Canada Solidarity Newsletter. While the "riff-raff of the Latin American left" statement would become the most well-known, other statements also pointed to Ambassador Ross welcoming the coup as a necessary evil, and characterized the UP as responsible for its own demise for having allowed "leftist extremists [to have] almost free rein." 53 The fact that the top Canadian government representative in Chile seemed to support the coup caused Harney and others to wonder whether the government was treating the refugee question as a humanitarian issue, or whether Ross' distaste for "leftist extremists" was leading to government inaction.

The revelations of the telegrams led activists both in Canada and on the ground in Chile to look more closely at how the embassy and the Department of Manpower and Immigration were dealing with asylum seekers and refugee claimants, and their findings were not encouraging. On 7 November, two Chilean churchmen and the foreign correspondent from Québec-Presse met with Ambassador Ross to discuss the refugee issue and the role Canada could play in it. Ross refused to consider granting asylum to a group of one hundred fugitives from the junta for whom the church officials were seeking shelter. Ross 
was also quoted as saying that Canada would accept Chileans who wanted to immigrate and met the criteria but not asylum seekers, whom he would even turn in to the authorities under certain circumstances. ${ }^{54}$ His comments indicated that, despite claims to the contrary, Canadian officials were treating requests for admission to Canada as an immigration issue rather than a humanitarian crisis.

The leaking of the Ross telegrams put the federal government on the defensive and led the cabinet to reexamine the way Ross, External Affairs and Manpower and Immigration were dealing with refugee claimants. On 15

November, cabinet called for a complete review of policy on Chile. According to a solidarity movement source, this showed that senior government officials were "upset by increasing evidence that what it hears from its 'intelligence' in Santiago is not an accurate description of the true situation in Chile." 55 Three fact-finding teams were then dispatched, one to Santiago and the other two to Panama and Honduras, where refugee claimants waiting for permission to enter third countries had congregated. The next day in the House of Commons, John Harney continued to press the issue. He motioned that "[T] his House instruct the government immediately to follow the measures adopted toward political refugees from Hungary...Czechoslovakia... and Uganda, thereby respecting the traditions which the Canadian people wish to have respected, and to instruct our embassies and affected departments to act accordingly." 56 Harney insinuated that representatives of the Canadian government were not obeying instructions nor acting according to humanitarian principles. Though his motion failed, it highlighted the contradictions between Canada's stated policy and what was happening in practice.

The gap between humanitarian rhetoric and the reality on the ground was further illustrated by a radio broadcast of the Canadian Broadcasting Corporation (CBC) programme As It Happens on 19 November. The correspondent reporting from Santiago disclosed the presence of two agents of the Royal Canadian Mounted Police (RCMP), which among its many roles at the time was the screening of people applying for entry to Canada who might pose a threat to national security. ${ }^{57}$ Commenting on the information, the Chile-Canada Solidarity Newsletter accused the federal government of putting political considerations ahead of compassion:

This news makes clearer the reason why the embassy filters in Santiago had approved fewer than 10 applications for immigration to Canada in the two months since the coup. If Canadian official paranoia about Communist and Socialists is applied to a situation where $40-50 \%$ of the population voted Communist or Socialist in the last few years, and where precisely these people are "under the gun", it becomes easy to explain the lack of response by Canadian officials: compassion blinded by ideology inappropriate to the circumstances. ${ }^{58}$ 
Details coming out of Chile reinforced the accusation that the situation was not being addressed adequately and that processing procedures and security screening were particularly intensive due to ideological concerns. The embassy in Santiago did not have enough translators or immigration operatives to deal with the number of applications, which sometimes reached over 1,000 a day. ${ }^{59}$ With the NDP leading the way in Parliament and bodies like the CCC and the LAWG lobbying tirelessly, pressure of the federal government was mounting just as evidence of institutional bias and perhaps incompetence was building. The Chilean lobby ensured that the issue was not going to disappear quietly and that the government would have to do more to alleviate the refugee situation.

\section{The Special Movement Chile}

On 29 November, Hortensia Bussi, the widow of Salvador Allende, attended the parliamentary session and had a brief private meeting with Prime Minister Pierre Trudeau. Though her pleas to make Canada a haven for "Chileans who wish to flee their country" only received a "non-committal nod," she reported afterward that Trudeau "promised an announcement today [30 November] of plans for bringing Chilean refugees to Canada." 60 The Prime Minister was as good as his word, and on 30 November, Manpower and Immigration Minister Robert Andras announced in the House the establishment of an emergency refugee admission programme called Special Movement Chile (SMC). After two and a half months of constant pressure, the Chilean lobby had secured a major victory: Canadian action with regard to Chileans would now be part of an official programme that would operate under guidelines similar to those of previous crises in Hungary, Czechoslovakia and Uganda.

In his speech, Andras began by praising the Canadian historical record in accepting people seeking refuge and mentioned the precedents that government critics had continuously used in arguing the Chileans' case. Noting that although "few people have expressed interest in immigrating to Canada" but were rather looking for a haven, the minister announced that selection criteria would be relaxed, meaning that individuals normally ineligible for immigration under the points system in use at the time would not be excluded automatically, although medical and security checks would continue. ${ }^{61}$ He promised accelerated immigration processing, along with language training, job placement services, and assistance to cover the costs of transportation, accommodation, winter clothing and "other such special support necessary to facilitate early establishment." Andras stated that special immigration teams were being dispatched to Santiago, Buenos Aires, Panama and Honduras to begin processing applicants under the Special Movement provisions and that the government expected "some hundreds" would end up in the country. In the conclusion of his state- 
ment, he called on the lobby groups who had forced the government to act to now take the initiative:

In the past, individuals and groups have always rallied to provide local support and assistance in welcoming displaced people to their new communities and helping them to become established quickly. For these efforts many thousands of Canadians deserve special praise. In the case of Chile, large numbers of Canadians in Church groups and other organisations have expressed their genuine concern in the welfare of those affected by the events in that country. We hope that again interested individuals and groups will join with the Government in the provision of special assistance for these people by contacting their nearest Canada Immigration Centre or Canada Manpower Centre. Many of the individuals now coming forward are young, well educated and adaptable people who, with a little help, can be expected to add their contribution to the richness and variety of Canada. ${ }^{62}$

Reaction to the announcement of the SMC in the House reflected a number of ideological positions present in the country. Jake Epp of the Progressive Conservatives voiced the Cold War concern about security, inquiring about the nationalities of the applicants and whether proper background checks would continue. Gérard Laprise of the right-wing Social Credit Party insisted that the applicants continue to be treated as normal immigration applicants and meet all requirements "to prevent Canada from becoming a refuge for all the riff-raff from all parts of the world." Speaking for the NDP, Andrew Brewin accused the government of not doing enough, an argument that would continue to be made by the Chilean lobby in the years to come. Brewin commented that the complacent nature of the government response up to that point had only been changed by the work of "a large section of the Canadian people. I refer particularly to the people in Québec and people in the churches who communicated with the government...indicating their deep concern about this matter." While acknowledging the need for background checks, Brewin stated that he hoped they would be done quickly and not be influenced by ideology:

I hope that a generous attitude will be taken and that political grounds will not be advanced as a reason for keeping these refugees out of Canada. It is all very well to call a person a Marxist and condemn him for that reason, but we are dealing with people whose lives are in danger and I hope political judgments will not be used to keep people out. ${ }^{63}$

The establishment of the SMC marked an important moment in the work of the solidarity movement and showed that sustained efforts could bring results. Using a combination of arguments to precedent, appeals to the sense of humanity of Canadians at all levels, and at times outright shame tactics, the coalition of leftist and progressive groups achieved one of their original goals. The process to admit refugees would be normalized, simplified and, it was hoped, divorced from the question of ideology. The Chilean solidarity movement 
seemed to have forced a reluctant government to act and to have won a great victory for activism over institutional suspicion and intransigence.

\section{Beyond the SMC: the ongoing struggle between security and humanitari- anism}

If I concluded this examination here, one might assume that the Chilean refugee question was solved by the SMC, and that after 30 November 1973, frictions between the federal government and the Chilean lobby ceased. To do so would paint a false picture. Far from being the end of the debate over admitting Chileans, the SMC ultimately represented only a partial victory for the solidarity lobby. The admission process became more transparent and codified, and Chileans who gained admission to Canada received material support from federal, provincial and municipal authorities, but there continued to be questions surrounding the Canadian effort. Lobbying by the Chilean solidarity coalition continued into 1974 and beyond as evidence emerged that Canadian officials continued to treat refugee claimants like normal immigrants and were still obsessed with weeding out people they considered terrorists.

A Manpower and Immigration memorandum from early 1974 is explicit in the perceived dangers Chileans posed to Canada. The author took issue with the argument that the Chilean issue was comparable to that of the Hungarians in 1956, the Czechoslovakians in 1968 or the Ugandans in 1972. He added "In the Chilean situation, security information is fairly readily available, and there are known to be extremists among the people seeking to leave Chile. We would actually be derelict in our responsibilities if we did not observe normal screening procedures." He emphasised the point that the 1951 United Nations Convention on Refugees does not preclude screening, and even allows for the expulsion of refugees if there are reasonable grounds for considering them a threat to the security of the receiving state. Given this fact, the author stated "It would seem to follow logically that refugees should, therefore, be subject to normal security screening procedures prior to their admission." With regard to the danger posed to Canada by Chilean leftists, he wrote

Professional or dedicated revolutionaries... are apt to regard the country which grants them asylum simply as a base from which they can continue their attempts to redress real or imagined wrongs. There is ample evidence in the world today that such people may even consider "aerial hijackings", bombings and assassinations as justifiable means of attaining their ends. Aside from the embarrassment such activities may cause the government, security screening of refugees, whether from the left or from the right, is an important and effective means of ensuring that our traditional hospitality toward all refugees is not undermined by granting undue consideration to this element. ${ }^{64}$ 
With this kind of attitude still present in immigration circles, the solidarity groups had to maintain their level of engagement. The United Church of Canada, an active CCC participant, published newsletters that decried the lethargic rate at which Manpower and Immigration processed claimants, and the small numbers of applicants accepted. ${ }^{65}$ Church delegations continued to meet with Ministers Andras and Sharp to make sure the federal government did not reduce its presence in Chile, which Andras had announced would happen in February 1974, claiming that all the "most urgent cases have been dealt with and the...need for special efforts is passed." 66 Groups such as LAWG publicized information about the Chilean situation, while solidarity groups across the country organized speaking tours by former UP members and Chilean refugees, concerts and peñas (traditional Chilean parties) to raise money for political prisoners in Chile and awareness among the Canadian public. ${ }^{67}$ While individual solidarity groups ran their own events and focused on a particular aspect of the solidarity campaign, at certain moments the diverse entities would ban together to petition the government. ${ }^{68}$ Joint action was particularly notable in October 1974 and March 1976, when solidarity movement representatives from a wide range of bodies presented collective reports to the federal government dealing with questions of human rights, financial relations and immigration. In both reports, the solidarity lobby appealed to the Canadian government to do more to help Chileans in danger and to relax admission criteria for refugee claimants. Even three years into the crisis, ideological concerns continued to restrict the number of Chileans accepted: "We are concerned, as we have stated in the past, that because of traditional security criteria, Canada has rejected or participated in the rejection of such a large proportion of applicants for refugee resettlement in Canada. We are dealing with refugees and not normal immigrants." 69 The SMC may have set the stage for the admission of larger numbers of Chileans, but it was only a temporary victory. Until the SMC ended in 1978, members of the solidarity movement had to keep the Chilean issue in the public eye to ensure that the government continued working on the problem in a manner that was consistent with the humanitarian approach it espoused. ${ }^{70}$

However, focusing only on the reluctance of Canadian officials would unfairly paint the government's eventual accomplishments in resettling Chileans. While government ministers were at first unwilling to set a quota for the number of Chileans who would be admitted, it was eventually set at 7,000, which compared very favourably with other nations sheltering exiles. ${ }^{71}$ The number of Chileans in Canada passed 10,000 by 1980, whereas there had been only 555 before $1971 .{ }^{72}$ A late 1976 Manpower and Immigration report gives us some idea of the rate of acceptance of applicants to the SMC to that point, where they ended up in Canada and what their occupations were. From September 1973 to the end of February, 1976, 5,620 Chileans had applied for entry to 
Canada as refugees or as members of an Oppressed Minority (OM), a special term used to cover persecuted individuals not eligible for refugee designation under the 1951 UN Convention definition of a refugee. ${ }^{73}$ Of this number, 4,420 had already been authorized to enter, 3,501 had landed, 970 were still in process, 100 political prisoners had been accepted, and 7,390 applicants had been refused or withdrawn their requests. Refusal for 590 cases included these general reasons: civil or settlement issues, 100; security reasons, 470; and health reasons, 20 cases. Of 3,097 landed Chileans, 12 were in Atlantic Canada, 695 in Québec, 920 in Ontario, 1,328 were in the three Prairie provinces (most of these in Alberta), and 142 Chileans had settled in British Columbia. Occupational information is very general, but breaks down in the following way: Skilled/professional, 645; semi-skilled, 398; unskilled, 207; and non-workers (dependents), 1,847.74 Though it is likely many Chileans who would have liked to take shelter in Canada did not get in because of the bias against their entry in certain government circles, effective lobbying by concerned groups did eventually ensure that a substantial group of mostly young, often highly educated and skilled Chileans did escape the repression in their homeland and find a space in which to recover from the trauma of their lives being turned upside down.

\section{The Chilean solidarity movement in perspective}

Despite the conflict among sectors of the government and the solidarity movement caused by the Chilean issue, the problem was not one that excited a largescale reaction in Canadian society. Chileans did not arrive in massive enough numbers between 1973 and 1978 to significantly change the demographic profile of the nation, and their contributions to Canadian society generally became apparent later, after several years in the country. The arrival of Chilean refugees did not suddenly cause most Canadians to look more closely and deeply at Latin America, nor examine their own country's position in the Cold War world and how it affected policy questions like refugee admission. The sudden growth of the Chilean community was not, in and of itself, a momentous event.

So why bother examining this subject at all? The answer to that lies in the changes to Canadian refugee and immigration law provoked by the Chilean presence, and in the development of an effective domestic pro-refugee and human rights lobby that coalesced around the issue. Though their contribution to these developments was inadvertent, the mere fact of them being in Canada or their desire to come here made the admission of Chileans significant.

The post-coup crisis in Chile contributed to the growth of a coalition of allied organisations in Canada that was active in a wide range of issues throughout the 1970s and 1980s, from denouncing military regimes in Latin America to protesting the apartheid regime in South Africa. This lobby, with the political left and church activists at its core, exerted enough pressure to achieve policy change at the federal level. Joan Simalchik, whose academic work has been 
cited in this study, co-founded the Toronto Action for Chile and served as the head of Canadian Committee for Solidarity with Democratic Chile from 1977 to 1983. In her writing on the Chilean refugee issue, she asserts that the ultimate effect of political actions on behalf of the first wave of Chileans was the creation of a distinct refugee category in the reformed 1976 Immigration Act, which went into effect in 1978. Lobbying over the Chilean issue had helped ensure that in refugee questions humanitarian considerations would be given priority over economic or political factors. ${ }^{75}$ This helped contribute more to Canada's international image as an open, humane country that would give a home to the persecuted, which culminated in the entire nation receiving the honour of the Nansen Refugee Award from the United Nations in 1986. Aside from the international laurels, the reforms spurred by the arrival of the Chileans helped other refugees, such as the Vietnamese, and strengthened Canadian civil society:

The thousands of Canadians involved with the "boat people", coupled with the coalitions created during the Chilean lobby, created a new prorefugee constituency in the larger civic culture. A developing refugee support network took shape. With roots in the mid-1970s work for Chilean refugees, community-based and professional agencies were created to assist in long term settlement needs (for example, education, language and skills training), specialized medical care, especially treatment for torture victims, sponsorship cases, refugee law and policy development. ${ }^{76}$

At the end of the day, Chileans coming to Canada may not have fundamentally altered the country, but the efforts made by solidarity activists to push for their admission provided the impetus for changes that have benefitted hundreds of thousands of persecuted people since. Though the impact was brought about by unhappy circumstance, the work of the Chilean solidarity movement left a significant mark on Canadian society.

\section{NOTES}

${ }^{1}$ During the military regime, the Chilean authorities put the number of people who fled or were expelled from the country as low as 30,000, while other sources put the number of political exiles only at over one million. In both cases, there were obvious political justifications for inflating or downplaying numbers. 200,000 seems to be a safe conservative estimate for political exiles, which appears in several sources: Jaime Llambias-Wolff, "Chile's Exiles and Their Return," in Robin Cohen, ed. The Cambridge Survey of World Migration. Cambridge: 
Cambridge University Press, 1995, 229; United Nations High Commissioner for Refugees, "La situación de los refugiados en el mundo 2000. Cincuenta años de acción humanitaria.” United Nations, 2000, 3; Organización Internacional para las Migraciones, "Las Migraciones Internacionales: Análisis y perspectivas para una Política Migratoria." Santiago, 2003, 5; a 1993 Chilean Senate statement puts it at 250000 (Legislatura 326a , Ordinaria Sesión del Congreso Pleno, May 21, 1993); also see Vicaría de la Solidaridad, "Documento de Trabajo," which has the number as 246,526 based on Investigative Police statistics. Centro de Documentación de la Vicaría de la Solidaridad (henceforth CDVS), Exilio, box 30. Vicaría de la Solidaridad, "Documento de Trabajo," 228.

2 In the mid-1980s, Canada ranked fourth with Italy, behind Venezuela, Spain and France. However, the data was by the authors' own admission incomplete as it did not include important countries of refuge such as Cuba and Mexico. Claudio and Marcela Duran, "Chilean Exile: The Uncertainties of Return." Refuge, Vol. 3, No. 3 (March 1984), 4.

3 With the exception of the political parties, all of the groups mentioned above along with several others participated in a report given to the ministers of External Affairs and Manpower and Immigration on October 9, 1974, titled "Canadian Policy Toward Chile." North American Congress on Latin America Archive of Latin Americana (henceforth NACLA-ALA). Chile, Roll 14, File 67, Canada-Chile Relations: 1968-1974. "Canadian Policy Toward Chile. Brief to the Honourable Allan J. MacEachern, Secretary of State for External Affairs, and the Honourable Robert K. Andras, Minister of Manpower and Immigration," 9 October 1974.

${ }^{4}$ José Del Pozo, Les Chiliens au Québec. Immigrants et réfugiés, de 1955 à nos jours (Montréal: Boréal, 2009); Julie Shayne, They Used to Call Us Witches: Chilean Exiles, Culture, and Feminism (New York: Lexington Books, 2009).

${ }^{5}$ Francis Peddie, "Young, Well-Educated and Adaptable People: Chilean exiles, identity and daily life in Canada, 1973 to the present day." Doctoral thesis in History, York University, 2012.

${ }^{6}$ Norman Hillmer, Bohdan Kordan, and Lubomyr Luciuk, eds. On Guard For Thee: War, Ethnicity, and the Canadian State, 1939- 1945 (Ottawa: Canadian Committee for the History of the Second World War, 1988), 242.

${ }^{7}$ Franca Iacovetta, Gatekeepers: Reshaping Immigrant Lives in Cold War Canada (Toronto: Between the Lines, 2006), 13-18.

8 Steven Volk, "Chile and History: The Meanings of 1973." NACLA Report of the Americas, Vol. XXVII, No. 2, (September/October 1993), 32.

9 Salvador Allende, Chile's Road to Socialism (Middlesex, England: Penguin Books, 1973), 140.

10 Colin Henfry and Bernardo Sorj, Chilean Voices (Hassock, England: The Harvester Press, 1977), 21-22. 
11 Joan Simalchik, "Part of the Great Awakening: Canadian Churches and the Chilean Refugees, 1970-1979." Master's thesis, University of Toronto, Toronto, Canada, 1993, 12.

12 The new Canadian approach to Latin America was enunciated in 1970 in a series of government publications, one of which was dedicated specifically to Latin America. Department of External Affairs, Foreign Policy for Canadians: Latin America (Ottawa: Information Canada, 1970). For the broader question of redefining Canada's role and how it impacted on policy toward Latin America, see Brian J.R. Stevenson, Canada, Latin America and the New Internationalism: A Foreign Policy Analysis, 1968-1990 (Montreal and Kingston: McGill-Queen's Press), 2000.

13 Simalchik, "Part of the Great Awakening," 13.

14 John Cleveland, "New Left, not new liberal: 1960s movements in English Canada and Quebec," Canadian Journal of Sociology and Anthropology 41, no. 4 (2004), 69-70.

15 Andrew S. Thompson, In Defence of Principles: NGOs and buman rights in Canada (Vancouver: University of British Columbia Press, 2010), 22.

16 In the first year of the UP mandate, GNP grew by $8.3 \%$ and industrial production by $12.9 \%$. Unemployment was reduced, inflation largely controlled, and considerable achievements were made in housing, nutrition programmes and health care. Some parts of the programme had the support of the opposition, such as the nationalization of copper resources at the expense of multinational corporations. Ricardo Israel Z., Politics and Ideology in Allende's Chile (Tempe, Arizona: Center for Latin American Studies, 1989), 34. Approval of the UP programme was such that in municipal elections in 1971, candidates from the coalition won $51 \%$ of the vote -the first time that the left had enjoyed majority support in any kind of election in Chilean history. "Green Light for the Generals", NACLA's Latin America and Empire Report, Vol. VIII, No. 8 (October 1973), 3.

17 The factors contributing to the breakdown of stability in Chile are outlined in "Green Light for the Generals," 3-10.

18 These were the words of Nixon to the head of the CIA in November, 1970. Harold Molineu, U.S. policy toward Latin America: from regionalism to globalism.

Second edition (Boulder: Westview Press, 1990), 167.

19 Israel Z., "Politics and Ideology in Allende's Chile," 43-44.

20 Jonathan Kandall, "Plotting the Coup", in Laurence Birns, The End of Chilean Democracy: An IDOC Dossier on the Coup and its Aftermath (New York: Seabury Press, 1974), 60. The article originally appeared in the New York Times, September 27, 1973, under the title "Chilean Officers Tell How They Began to Plan the Take-Over Last November."

21 In June 1973, Salvador Allende stated in a speech that "Chile knows that, for its tradition and history, the Armed Forces will never use the arms the people 
have given them against the people themselves." Quoted in Eugenio Ahumada et al, eds. Chile: la memoria probibida. Vol. I, Fourth edition (Santaigo: Pehuén, 1990), 5.

22 Kandall, "Plotting the Coup," 60.

23 Ibid., 65.

24 "Extirpate the Marxist cancer" was a phrase used by Air Force General Gustavo Leigh on the night of September 11, 1973, when the junta members addressed the nation to explain and justify their actions.

25 Pamela Constable and Arturo Valenzuela, A Nation of Enemies: Chile under Pinochet (New York: Norton and Co., 1991), 20.

26 Chicago Commission of Inquiry into the Status of Human Rights in Chile, Report of the Chicago Commission of Inquiry into the Status of Human Rights in Chile. Santiago, Chile, February 16-23, 1974.” Chicago, 1974, 3-4.

27 Alan Angell and Susan Carstairs, "The Exile Question in Chilean Politics," Third World Quarterly, Vol. 9, No. 1 (January 1987), 166.

28 Government of Canada, House of Commons Debates (henceforth HC Debates), September 18, 1973. $1^{\text {st }}$ session, 29 th Parliament, Volume VI, 6667. 29 NACLA-ALA. Chile, Roll 26, File 138, Solidarity Organisations: Canada. Miscellaneous documents, 1973-1989. Telex, Ross to External Affairs, 13 September 1973.

30 NACLA-ALA. Chile, Roll 26, File 138, Solidarity Organisations: Canada. Miscellaneous documents, 1973-1989. Telex, Ross to External Affairs, 20 September 1973.

31 NACLA-ALA. Chile, Roll 26, File 138, Solidarity Organisations: Canada. Miscellaneous documents, 1973-1989. Telex, Ross to External Affairs, 24 September 1973.

32 Simalchik, "Part of the Great Awakening," 19-20. The Latin American Working Group in Toronto was founded in 1966, and described itself "an independent research, education and action collective" interested in promoting greater understanding of Latin America among Canadians.

33 Ibid., 23.

34 No author cited, "Praise and condemnation greet coup" Toronto Star, 12 September 1973, A12.

35 HC Debates 1/29, Volume VI, 13 September 1973, 6495.

36 No author cited, "Les syndicats experiment leur consternation devant la fin tragique du régime Allende." Le Devoir, 13 September 1973, 7.

37 Text reproduced in Cathy Carroll, Bob Carty and John Foster, "Chilean

Refugees- Canada's reluctant response." United Church of Canada Newsletter, No. 3, March 1974, 3.

38 Carroll et al, "Chilean Refugees," 3. 
39 Quoted in Gerald E. Dirks, Canada's Refugee Policy: Indifference or Opportunism? Montreal and London: McGill-Queen's University Press, 1977, 246.

40 No author cited, "Chilean students parade in Ottawa to protest junta." Toronto Star, 21 September 1973, A10.

41 Simalchik, "Part of the Great Awakening," 28.

42 No author cited, "Trois prêtres canadiens font le récit du cauchemar qu'ils ont vécu au Chili." Le Devoir, 28 September 1973, 1.

43 Simalchik, "Part of the Great Awakening," 28.

44 Robin Enders et al, "York Committee protests military takeover in Chile, concerned student says." Toronto Star, 24 September 1973, C5.

45 Julie D. Shayne They Used to Call Us Witches: Chilean exiles, culture, and feminism (Lanham, Maryland: Rowman and Littlefield Publishers, 2009), 82-83.

46 Shayne, They Used to Call us Witches, 83. By September 1974 the programme had succeeded in placing approximately $20 \%$ of its candidates.

47 Carroll et al, "Chilean Refugees," 3.

48 HC Debates 1/29, Volume VII, 15 October 1973, 6858.

49 Ibid.

50 Chile-Canada Solidarity Newsletter, No. 7, 25 November 1973, 3.

51 Carroll et al, "Chilean Refugees," 3.

52 HC Debates 1/29, Volume VII, 5 November 1973, 7504.

53 NACLA-ALA. Chile, Roll 26, File 138, Solidarity Organisations: Canada.

Miscellaneous documents, 1973-1989. Telex, Ross to External Affairs, 24

September 1973.

54 NACLA-ALA .Chile, Roll 26, File 139, Solidarity Organisations: Canada.

Miscellaneous documents, 1973-1989. Serge Mongeau, C.B and F.N. interview with Andrew Ross, November 7, 1973. The transcript was reproduced in the Chile-Canada Solidarity Newsletter, No. 7, 25 November 1973, 7-11.

55 NACLA-ALA.Chile, Roll 26, File 139, Solidarity Organisations: Canada. Miscellaneous documents, 1973-1989. No author cited, Chile-Canada Solidarity Newsletter, No. 7, 25 November 1973, 6.

56 HC Debates 1/29, Volume VII, 16 November 1973, 7862.

57 RCMP officers were responsible for "Stage B" security investigations. Stage B involved background security checks undertaken after it was determined whether an applicant met the minimum level under the points system, and was often quite time-consuming. These checks were designed to weed out anyone with a criminal background, a history of mental health problems or anti-social behaviour, and potential revolutionaries or terrorists.

58 NACLA-ALA. Chile, Roll 26, File 139, Solidarity Organisations: Canada. Miscellaneous documents, 1973-1989. No author cited, Chile-Canada Solidarity Newsletter No. 7, 25 November 1973, 6. 
59 Simalchik, "Part of the Great Awakening," 37-38.

${ }^{60}$ No author cited, "PM asked to help Chilean refugees." Toronto Star, 30 November 1973, A18.

61 The points system had been introduced under 1967 reforms to the Immigration Act. The criteria for admittance was based on the following areas: education and training; personal assessment; occupational demand; occupational skill; age; knowledge of English or French; relatives in Canada; and employment opportunities in the destination area. A score of 50 points or over out of 100 would qualify a person for admittance. Less than that would mean the individual was "Not suitable for permanent residence" and would be refused entry.

62 HC Debates 1/29, Volume VIII, 30 November 1973, 8297.

63 All quotations from these two pages are from HC Debates 1/29, Volume VIII, 30 November 1973, 8298-8299.

${ }^{64}$ Library and Archives Canada (henceforth LAC), RG 76 Vol. 986 File 5781-3-

3, Refugees-Chilean Movement. Processing of Applications, Stage "B" (Security) Vol. 1. "Chilean Refugees- Security Screening," 10 January 1974. Due to Access to Information protocols, I cannot use the names or job titles of document authors.

65 According to March 1974 statistics, 36\% of refugee claimants and 94\% of those applying as immigrants had been rejected by immigration authorities in Santiago. Carroll et al, "Chilean Refugees," 1.

66 Carroll et al, "Chilean Refugees," 3.

67 Shayne, They Used to Call us Witches, 109.

68 Simalchik, "Part of the Great Awakening," 43. She gives the example of the CCC focusing on government lobbying and press liaison, the Toronto Welcome Committee taking charge of refugee reception, and the Canada Chile Fund being responsible for the financial aspect of the campaigns.

${ }^{69}$ NACLA-ALA.Chile, Roll 26, File 139, Solidarity Organisations: Canada.

Miscellaneous documents, 1973-1989. The Coalition on Canadian Policy toward Chile, “Canada and the Rights of Chilean People." March 1974, 23.

70 Simalchik, "Part of the Great Awakening," 40.

71 Oñate et al state that Canada and Sweden both gave shelter to $9 \%$ of the total exile population, exceeded only by France at 10\%. They do not, however, provide solid numbers or explain how they define who is an exile, which leads me to believe that they have chosen to include most people who entered Canada during the years of the military government. Rody Oñate, Thomas Wright, Caroline Espinoza, Andrea Soto and Ximena Galleguillos. Exilio y retorno. Santiago: LOM, 2005, 44.

72 Statistics Canada, "Hispanic Spanish speaking population in Canada: a special report prepared for the Canadian Hispanic Congress." 2006, 36. This census report places the exact number at 10915 ; another source puts the number of 
Chileans at 15697 in 1980, amounting to $3.85 \%$ of the exile population. CDVS, Exilio, box 30. Documento de Trabajo (Working Document) of the Vicaria de la Solidaridad, 1992, 230, 233.

73 A refugee is defined as "Someone who, owing to a well-founded fear of being persecuted for reasons of race, religion, nationality, membership of a particular social group or political opinion, is outside the country of his nationality and is unable or, owing to such fear, is unwilling to avail himself of the protection of that country; or who, not having a nationality and being outside the country of his former habitual residence as a result of such events, is unable or, owing to such fear, is unwilling to return to it."

74 LAC RG 76 Vol. 986 File 5781-1 Refugees-Chilean Movement General. “Chilean Refugees Accepted for Permanent or Temporary Resettlement." No date, most likely late 1976.

75 Simalchik, "Part of the Great Awakening," 3-9.

76 Ibid., 81-82. 